\title{
Germination and seed conservation of a pioneer species, Tecoma stans (Bignoniaceae), from tropical dry forest of Colombia
}

\author{
Jhon Alexander Vargas-Figueroa \& Alba Marina Torres-González \\ Grupo de Investigación Ecología y Diversidad Vegetal, Departamento de Biología, Facultad de Ciencias Naturales y \\ Exactas, Universidad del Valle, Calle 13 No.100-00, Cali, Colombia; vargas.jhon@correounivalle.edu.co*, \\ alba.torres@correounivalle.edu.co \\ * Correspondence
}

Received 08-VIII-2017. C Corrected 10-I-2018. Accepted 06-II-2018.

\begin{abstract}
Seed germination and seed longevity under different environmental conditions are fundamental to understand the ecological dynamics of a species, since they are decisive for its success within the ecosystem. Taking this into account, seed germination and seed storage behavior of a pioneer species of tropical dry forest (Tecoma stans) were studied in the laboratory, to establish the effect of different environmental conditions on a local tree population. Two seed lots collected in July 2011, from Cali (Colombia), were evaluated under three alternating temperatures $\left(20 / 30,20 / 25,25 / 30^{\circ} \mathrm{C} ; 16 / 8 \mathrm{~h}\right)$ and four light qualities (12-hour white light photoperiod, darkness, and 15 minutes of red light $-\mathrm{R}$ and far red light -FR). Final germination was recorded for all treatments; for white light treatment the daily germination was recorded to calculate mean germination rate, mean germination time, and two synchronization indices. To assess the effect of light quality on physiological variables, a destructive germination test was carried out. For this test, another seed lot was evaluated under the same light conditions using an alternating temperature of $20 / 30{ }^{\circ} \mathrm{C}-16 / 8 \mathrm{~h}$, recording germination during six days for every treatment. In addition, seeds were stored at two different moisture contents $(7.7,4.1 \%)$ and three storage temperatures $\left(20,5,-20{ }^{\circ} \mathrm{C}\right)$, during two time periods (one and three months); a seed germination test was conducted for each treatment. Four replicates of 35 seeds per treatment were used for all experiments. Germination was high $(\mathrm{GP}>90 \%)$ with all alternating temperatures under white light, whereas under R, FR, and darkness germination was evenly successful at low temperatures, but at higher temperature, half of the seeds entered into secondary dormancy $(\mathrm{GP}=45-65 \%)$. However, mean germination rate and synchronization under $\mathrm{R}$ and FR decreased significantly in comparison to white light treatment and, consequently, mean germination time increased. Seed storage behavior of this species is orthodox due to the high germination (GP $>90 \%$ ) obtained under all treatments. In conclusion, T. stans seeds have a negative germination response at high incubation temperatures in the absence of white light, entering into a secondary dormancy. In contrast, an environment with a lower temperature and without white light delays the germination, but at the end seeds are able to reach the same germination values. This seed dependence on incident light in limiting conditions suggests a physiological mechanism on the seed tissues of this species, probably mediated by phytochromes. Finally, the orthodox seed storage behavior of $T$. stans is a reason to include this species in ex situ seed conservation programs for restoration and recovery of the tropical dry forest; however, long-term studies should be conducted in order to evaluate the maintenance of this characteristic throughout longer periods of time. Rev. Biol. Trop. 66(2): 918936. Epub 2018 June 01.
\end{abstract}

Key words: secondary dormancy; phytochrome; soil seed bank; seed storage behavior; ex situ conservation; climate change.

Tropical dry forest is a form of vegetation located in lowland territories with certain climatic conditions (i.e. annual mean temperature above $17^{\circ} \mathrm{C}$, annual rainfall between 250 and $2000 \mathrm{~mm}^{3}$, annual evapotranspiration/ precipitation rate less than 1.0 ), which tend to be seasonal, with months marked by drought, followed by months with heavy rainfall (Dirzo, Young, Mooney, \& Ceballos, 2011; Mooney, Bullock, \& Medina, 1995). Climatic conditions 
with marked weather differences and seasonality put pressure on the flora and fauna inhabiting this ecosystem, resulting in the development of a series of morphophysiological adaptations that directly influence dry forest ecosystem processes (Arcila, Valderrama, \& Chacón, 2012; Díaz, 2006). Some of these groups of adaptations are involved directly or indirectly with germination. In general terms, rapid germination, expressed as many seeds emerging in a short time (e.g. days) after the start of the rainy season, has been proposed as a successful strategy for any tree living in these ecosystems (Vargas, Werden, \& Powers, 2015). These processes have great relevance for the major questions of germination ecology: what controls the process of seed germination in nature? and what are the origins and consequences of these ecological and evolutionary processes of germination? (Baskin \& Baskin, 2014).

The germination processes occurring in different locations in the understory of an ecosystem may be reflected in different patterns, depending on species' responses to such variables as temperature, light, humidity, among others (Bewley, 1997). In the case of dry forests, approximately $31 \%$ of the tree species and approximately $18 \%$ of the shrubs have seeds without dormancy, that is, seeds germinate quickly in favorable environmental conditions; the remaining species studied in these habits exhibit some type of dormancy, being physiological dormancy the most common in trees (37\%) and physical dormancy in shrubs (52 \%) (Baskin \& Baskin, 2014). However, most species of Fabaceae, the family with the highest species richness in dry forests, have physical dormancy (Ceccon, Olmsted, Vázquez-Yanes, \& Campo-Alves, 2002). Many species, and in some cases even different populations of the same species, have different requirements for germination. In dry forests, for example, the average temperature required for a large number of seeds of tree species to germinate is 26.9 $\pm 0.2{ }^{\circ} \mathrm{C}$; in the case of shrub species, it is 26.5 $\pm 0.8{ }^{\circ} \mathrm{C}$ (Baskin \& Baskin, 2014). However, some tree species require the incidence of light to germinate, whereas no shrub species have been reported to require light for germination. Data may be lacking on the germination response of shrub species to the quantity and quality of ambient light. In many cases, the seeds of dry forest species have a higher percentage of germination in shaded locations than in bright sunlight ones, and this is true for the establishment of seedlings as well (Khurana \& Singh, 2000). However, individual trees tend to show a major growth in open sites, such as forest gaps (McLaren \& McDonald, 2003; Vieira \& Scariot, 2006).

On the other hand, seeds of different ecosystems can vary in their storage behavior (i.e., orthodox, recalcitrant, intermediate seeds) (Hong \& Ellis 1996), which may reflect the ability of a certain species' seeds to remain viable under conditions where temperature and moisture are very low. Species with orthodox seeds tolerate desiccation and maintain their viability in very cold storage conditions, whereas recalcitrant seeds lose their viability under those conditions (Roberts, 1973); intermediate seeds can't tolerate subzero temperatures but can tolerate partial desiccation (Ellis, Hong, \& Roberts, 1990). In seasonal ecosystems like tropical dry forests, seeds dispersed in the rainy season are expected to show more desiccation sensitivity than those dispersed in the dry season (Farnsworth, 2000). In this sense, a trend might exists in the storage behavior of dry ecosystem species, whereby recalcitrant species tend to produce seeds in the rainy season and orthodox species produce seeds in the dry season (Perera, 2007), but this hypothesis has yet to be tested. In the dry forests of the Cauca River valley in Colombia, species that tend to produce fruit during the dry season (Cárdenas-Henao et al., 2015) also display orthodox behavior (Vargas-Figueroa, Duque-Palacio, \& Torres-González, 2015). However, Jacaranda caucana, a Bignoniaceae whose seeds are orthodox (Vargas-Figueroa et al., 2015), produces fruit in the dry season that remains on the tree for a long time (CárdenasHenao et al., 2015); therefore, some orthodox seeds might be dispersed at different times in 
these forests, showing that this relation might not be causal.

Tecoma stans (L.) Juss. ex Kunth (Bignoniaceae) is a shrub or tree of middle levels found from the Southern United States to Northern Argentina. In Colombia, this plant is found mainly in the Andes and the Caribbean but is cultivated in tropical and subtropical regions (Gentry, 2009). This species produces large quantities of seeds dispersed by the wind (Pelton, 1964), mainly in dry seasons (RojasRodríguez \& Torres-Córdoba, 2012). While the species is used to reforest degraded sites (Chízmar, De Gracia, \& Hoyos, 2015; Otsamo, Adjers, Hadi, Kuusipalo, \& Vuokko, 1997), it is considered highly invasive in many places where it has been introduced as an ornamental or medicinal plant (Da Silva, Reis, \& Reis, 2008; Lorenzi, 2000; Madire, Wood, Williams, \& Neser, 2011; Reis et al., 2014; Ziller, 2001). T. stans is typical of dry forests in a relatively early successional state or in places dominated by subxerophytic scrub vegetation and in welldrained and/or rocky soils, although it may also be found in areas of pre-mountain and mountain rainforest (Pelton, 1964).

The requirements for the germination of $T$. stans seeds have been documented for populations located in Mexico, the United States, and the Netherlands Antilles, where it is native (Alvarado-López, Soriano, Velázquez, OrozcoSegovia, \& Gamboa-deBuen, 2014; Pelton, 1964), and in Brazil, where it is an introduced species (Reis et al., 2014; Socolowski, Vieira, \& Takaki, 2008). Populations of T. stans located North of the species' distribution germinate in approximately two days at a constant temperature of $20^{\circ} \mathrm{C}$, thus displaying no dormancy and being indifference to light; seeds can even germinate if they left floating in water (Pelton, 1964). In Mexico, seeds exposed to prior treatment by hydration and dehydration before germination (i.e. priming) germinated in a shorter average time than seeds without prior treatment; that is, priming speeds the seeds' germination (Alvarado-López et al., 2014). On the other hand, populations introduced into Brazil and located in places where they have become invasive have a highly favorable germination response (approximately $90 \%$ ) at both constant temperature (ranging from $15{ }^{\circ} \mathrm{C}$ to $40{ }^{\circ} \mathrm{C}$ ) and alternating temperatures $\left(20 / 30{ }^{\circ} \mathrm{C}\right.$ for $16 / 8$ h) (Socolowski et al., 2008). However, a difference in germination response was recorded when seeds were put in the dark, which some of the seeds apparently entered to a secondary dormancy when the temperature was very low or very high. Finally, the germination rate in T. stans is affected by constant temperature and by the presence or absence of light, with an optimal germination temperature of $\sim 30{ }^{\circ} \mathrm{C}$ (Socolowski et al., 2008).

Regarding the storage behavior, the low water content of $T$. stans seeds at dispersal (i.e., 7-12\%) (Vargas-Figueroa 2012), the type of fruit (i.e. dry, dehiscent capsule) (Gentry, 2009) and the type of seed dispersal (i.e. anemochorous) (Pelton, 1964) suggest that their seeds has an orthodox storage behavior (Hong \& Ellis, 1996). Moreover, pioneer species and species of tropical dry ecosystem are more likely to register this behavior (Tweddle, Dickie, Baskin, \& Baskin, 2003). However, it seems that this trait has not been experimentally evaluated from natural populations of this species (RBG, 2017); besides, species with dormancy are expected to show high tolerance to desiccation and T. stans doesn't have this condition (Vargas-Figueroa, 2012). Nevertheless, seeds of $T$. stans with an internal moisture of $7.2 \%$ stored at laboratory temperature $\left(\sim 20^{\circ} \mathrm{C}\right)$ for four years showed no significant decrease in germination (Pelton, 1964), so they appear to be resistant to desiccation. Knowledge of longterm storage behavior of seeds is crucial to seed bank programs aimed at ecological restoration and conservation in the tropics (Leon-Lobos, Way, Aranda, \& Lima, 2012).

The physiological characteristics of a species' seeds, such as their germination capacity and longevity under different environmental conditions, are the basis for understanding the species ecological dynamics, as they determine in part the species potential for success in each ecosystem. Yet, knowledge about these aspects of forest species in neotropical regions remains 
scarce. In addition, a demand exists for studies on the germination and seedling growth of tropical dry forest species to develop ecological restoration plans that take into account the different requirements for germination and establishment in these ecosystems (Quesada et al., 2009). In the context of climate change, prolonged drought can affect fruit and seed production, germination patterns, and plant survival and development, among other processes (Ceccon \& Hernández, 2009). In fact, the significant changing in temperature and rainfall associated with global climate change alter the environmental signals that guide seed germination, thereby promoting or retarding the regrow (Walck, Hidayati, Dixon, Thompson, \& Poschlod, 2011). Accordingly, improving our knowledge of current germination dynamics among the different species native to dry ecosystems is important for the development of germination protocols for restoration plans appropriate to the current climatic situation.

This study evaluated the germination response and storage behavior of seeds of a population of T. stans (Bignoniaceae) located in dry forests of the Cauca River valley, Colombia, to determine the variation of these physiological characteristics at the local level as an input for future regional and global scale studies. Thus, the following questions were raised: (1) what is the effect of light quality and temperature fluctuation on germination of a pioneer species population from tropical dry forest? and (2) what storage behavior do this seed population display (i.e. orthodox, intermediate, recalcitrant)?

\section{MATERIAL AND METHODS}

Seed material: Mature fruits were collected from eight Tecoma stans healthy trees in two locations at the city of Santiago de Cali, department of Valle del Cauca, Colombia ( $3^{\circ} 22^{\prime} 37.1^{\prime \prime}$ - 3 ${ }^{\circ} 20^{\prime} 55.27^{\prime \prime} \mathrm{N} \& 76^{\circ} 31^{\prime} 53.5^{\prime \prime}$ - 76³4'2.17" W, 960-1 $170 \mathrm{~m}$ of altitude). Two seed lots were collected in two different months of the dry season. The fruits mean size were $18.51 \pm 2.72$ $\mathrm{cm}$ in length $(\mathrm{n}=257)$. The locations belong to the tropical dry forest according to Holdridge (Espinal \& Montenegro, 1977). This locations have a mean temperature of $25^{\circ} \mathrm{C}$, an annual precipitation of $908 \mathrm{~mm}$ and a relative humidity of $73 \%$ (Cárdenas-Henao et al., 2015). Voucher samples were collected from one single tree of each location and were placed in the CUVC Herbarium of Universidad del Valle, Cali, Colombia (J.A.Vargas-Figueroa: \#194 - CUVC57969 and CUVC57970; \#222 CUVC58534 and CUVC58535).

The seed extraction and the tests were performed at the Seed Laboratory of Universidad del Valle. Given the external morphological variability of $T$. stans seeds, a prior selection of the viable seeds was made, following the morphological description of Bignoniaceae seeds by Bittencourt and Semir (2005), which were confirmed by viability testing with Triphenyl Tetrazolium Chloride - TTC (i.e. non-scarified seeds in water solution of TTC at $0.5 \%, 35^{\circ} \mathrm{C}$ for $24 \mathrm{~h}$ ) (Vargas-Figueroa, 2012). A general morphometric description of the seeds and the moisture content of seed population are showed in Table 1.

\section{Evaluation of the effect of temperature} on physiological variables: A germination test was made varying the alternating temperature to calculate the mean germination velocity or rate, (Nichols \& Heydecker, 1968), the mean germination time, (Ranal \& Santana, 2006), and two synchronization indices, $Z$ index (Primack, 1980) and $E$ index (Labouriaou \& Valadares, 1976). Three alternating temperatures were used (i.e. $20 / 25,20 / 30$ and $25 / 30^{\circ} \mathrm{C}$, for $16 / 8 \mathrm{~h}$ ), based on the mean, minimum and maximum temperatures of Cali, Colombia (IDEAM, 2005). For all treatments, DiEs incubators $\mathrm{K} 115 \mathrm{U}$ and $\mathrm{KU} 115 \mathrm{~F}$ were used, with temperature control and a photoperiod of 12/12 hours of white light and darkness, respectively. Four replicates of 30 seeds each were set in Petri dishes with absorbent paper. The amount of germinated seeds per day was recorded (i.e radicle protrusion $>1 \mathrm{~mm}$ ), which was expressed as a percentage (GP). 
TABLE 1

Morphometric description, weight and moisture content of Tecoma stans seeds lots $(\mathrm{n}=102)$

\begin{tabular}{lcccc}
\multicolumn{1}{c}{ Measure $^{*}$} & Mean \pm SD & Maximum value & Minimum value & Coefficient of variation \\
Seed length, including wings (mm) & $24.57 \pm 2.17$ & 28.58 & 20.21 & 8.83 \\
Seed width, including wings (mm) & $5.04 \pm 0.36$ & 5.93 & 3.96 & 7.23 \\
Seed length, excluding wings (mm) & $4.71 \pm 0.30$ & 5.61 & 3.59 & 6.47 \\
Seed width, excluding wings (mm) & $3.19 \pm 0.20$ & 3.45 & 2.67 & 6.33 \\
Seed thickness (mm) & $0.47 \pm 0.05$ & 0.59 & 0.35 & 10.77 \\
Hilum length (mm) & $0.86 \pm 0.16$ & 1.31 & 0.52 & 18.34 \\
Hilum width (mm) & $0.45 \pm 0.08$ & 0.60 & 0.28 & 17.66 \\
Seed weight $(\mathrm{g})$ & $0.0039 \pm 0.0007$ & 0.0057 & 0.0026 & 16.3900 \\
Moisture content ${ }^{1}(\%)$ & $7.7 \pm 0.7$ & - & - & - \\
\hline
\end{tabular}

SD: Standard Deviation.

Seeds were measured as soon as the fruit opened.

${ }^{1} 10$ replicated of $1.0 \mathrm{~g}$ each one, at $130{ }^{\circ} \mathrm{C}$ for one hour, following Vargas-Figueroa (2012) and the rules of the International Seed Testing Association (ISTA, 2017).

Evaluation of the effect of light and temperature on germination: A factorial experiment of $2 \times 3 \times 4$ was made, for a total of 24 treatments, which consisted in (1) two seed lots, (2) three alternating temperatures (i.e. $20 / 25,20 / 30$ and $25 / 30^{\circ} \mathrm{C}$ for $16 / 8 \mathrm{~h}$ ) and (3) four light qualities (i.e. photoperiod of 12 hours of white light to simulated conditions of open areas and big gap forests, total darkness to simulate conditions of burial and soil seed banks, a pulse of light with high red:far red ration - $\mathrm{R}$ for 15 minutes to simulate conditions of small gap forest, and a pulse of light with low red:far red ration - FR for 15 minutes to simulate conditions of understory with closed canopy and seeds under litter). To achieve a total darkness environment, two black bags of high-density polyethylene - HDPE were used. Simulation of red light (i.e. $640-670 \mathrm{~nm}$, pick in $660 \mathrm{~nm}$ ) was achieved with two fluorescent tubes of white light of $20 \mathrm{w}$ (Sylvania F20T12/D) with irradiance of $100.1 \mu$ mol.m-2.s-1 and R:FR = 0.00102. Simulation of far red light (i.e. 690$748 \mathrm{~nm}$, pick in $730 \mathrm{~nm}$ ) was achieved with two Lee Filter layers No. 26 and one No. 120, to filter the light produced by two incandescent bulbs of $60 \mathrm{w}$ (Sylvania E-27) with irradiance of $3.31 \mu$ mol.m-2.s-1 and R:RL $=5.40045$ (Benvenuti, Macchia, \& Miele, 2001; Escobar $\&$ Torres, 2013; Vargas-Figueroa et al., 2015).
Prior treatments of R and FR lights were performed only once during 15 minutes, using a wood-made dark chamber, after which samples were transferred to the incubators (Escobar \& Torres, 2013; Vargas-Figueroa et al., 2015).

Because phytochrome is not sensitive to light when seeds are dehydrated (Kendrick \& Spruit, 1977; McCullough \& Shropshire, 1970), T. stans seeds were soaked in deionized water for 30 minutes. Seeds of photoperiod treatments were soaked in light environment and the amount of germinated seeds per day was registered (radicle protrusion $>1 \mathrm{~mm}$ ). The rest of the seeds were soaked in completely darkness (i.e. inside two HDPE bags), before the stimulation with each light quality, and only the final amount of germinated seeds were registered.

Evaluation of the germination over time: A destructive germination experiment was made (Baskin \& Baskin, 2014) to evaluate the effect of the light quality in the germination rate and germination time. The treatments were (1) four light qualities, as ones described before, and (2) five checking times, with a daily check starting the second day after the initiation of the test. The alternating temperature was $20 / 30{ }^{\circ} \mathrm{C}$ for $16 / 8 \mathrm{~h}$. Each checked 
treatment was discarded due to a possible effect of incident light over germination process.

Determination of the type of seed storage behavior: Following the protocol described by Hong and Ellis (1996), a factorial experiment of $3 \times 2 \times 2$ was made, for a total of 12 storage treatments, which consisted in (1) three constant temperatures of storage (i.e. $20^{\circ} \mathrm{C}, 5^{\circ} \mathrm{C}$, $-20^{\circ} \mathrm{C}$ ), (2) two moisture content - MC (i.e. $7.7 \%, 4.1 \%$ ) and (3) two storage times (i.e. one month, three months). The seed $\mathrm{MC}$ at fruit extraction was $7.7 \%$. To obtain $4.1 \%$ of $\mathrm{MC}$, a portion of the seed lot was maintain in a muslin bag, inside a silica-gel glass hermetic chamber for $24 \mathrm{~h}$. The groups of seeds of every treatment were vacuum packed in aluminum bags with a Fuji Impulse sealer V-300 and were storage in cold rooms at the Genetic Resources Unit of CIAT (International Center of Tropical Agriculture, Valle del Cauca, Colombia), at the three constant temperature. Germination tests were made at alternating temperature of $25 / 30$ ${ }^{\circ} \mathrm{C}$ for $16 / 8 \mathrm{~h}$ to determine the seed viability before and after each storage treatment.

Data were analyzed using Minitab ${ }^{\circledR}$ 16.1.0 Statistical Software program (Minitab Inc.). Germination percentage (GP) were transformed using arcsine function, following Zar (2010). In order to test the effect of light and temperature in the germination process and the potential differences between seed lots, two way ANOVA and Tukey tests were made for posterior comparisons, using a significance level of $95 \%(\alpha=0.05)$. In order to test the effect of temperature in the mean germination rate, the mean germination time and the synchronization of germination and also potential differences between seed lots, a General Lineal Model (GLM) were used, where the factor variable of each analysis was the alternating temperature and the response variable were the physiological variable (i.e. mean germination rate, mean germination time, $Z$ index, $E$ index). In the GLM, a Tukey tests for posterior comparisons were used, with the same significance level. Finally, germination percentages of the seed storage behavior test were also transformed with arcsine function and factorial ANOVAs and Tukey tests were used to evaluate the effect of temperature, moisture content and the storage time on the viability of the seeds, using the same significance level.

\section{RESULTS}

Effect of temperature on physiological variables: Seed germination rates were high in all alternating temperatures and in both seed lots, with GP values close to $100 \%$ (Table 2). The small differences in the GP values at the temperatures for each lot and between lots were not significant (Tukey, $0.481 \leq \mathrm{P} \leq 1.000$ ). The germination process under these temperature conditions occurred from 3.02 to 5.05 days in terms of mean germination time, which corresponds to a mean germination rate of 0.20 to 0.33 seeds per day. In lot one, the mean germination rate and the mean germination time were statistically similar at each alternating temperature (Tukey, rate: $0.990 \leq \mathrm{P} \leq 0.999$, time: $0.846 \leq \mathrm{P} \leq 0.999)$. In contrast, in lot two, the mean germination rate was significantly lower for the temperature of $25 / 30^{\circ} \mathrm{C}$, compared to the other two temperatures, and hence, the mean germination time was significantly greater (Tukey, $\mathrm{P}=0.000157$ for both variables). The differences in mean germination rate and mean germination time between temperatures of $20 / 30{ }^{\circ} \mathrm{C}$ and $20 / 25^{\circ} \mathrm{C}$ in this lot were significant but low (Tukey, rate: $\mathrm{P}=0.013$; time: $\mathrm{P}=0.021)$. The differences in mean rate and mean time between lots were significant (Tukey, $\mathrm{P}=0.000157$ for both variables in all comparisons), so in fact, the seeds of lot two germinated faster than those of lot one. Regarding the synchronization indices, the germination process was highly synchronized in all alternating temperature for lot one (Tukey, $Z$ : $0.176 \leq \mathrm{P} \leq 0.827$; E: $0.567 \leq \mathrm{P} \leq 0.991)$, and this synchronization was statistically similar to the synchronization recorded at the temperature of $25 / 30{ }^{\circ} \mathrm{C}$ for lot two (Tukey, $Z$ : $0.610 \leq \mathrm{P} \leq$ $0.999 ; E: \leq \mathrm{P} \leq 0.994)$. This synchronization differed from that recorded at temperatures of 20/25 ${ }^{\circ} \mathrm{C}$ and $20 / 30{ }^{\circ} \mathrm{C}$ for lot two (Tukey, $Z$ : 


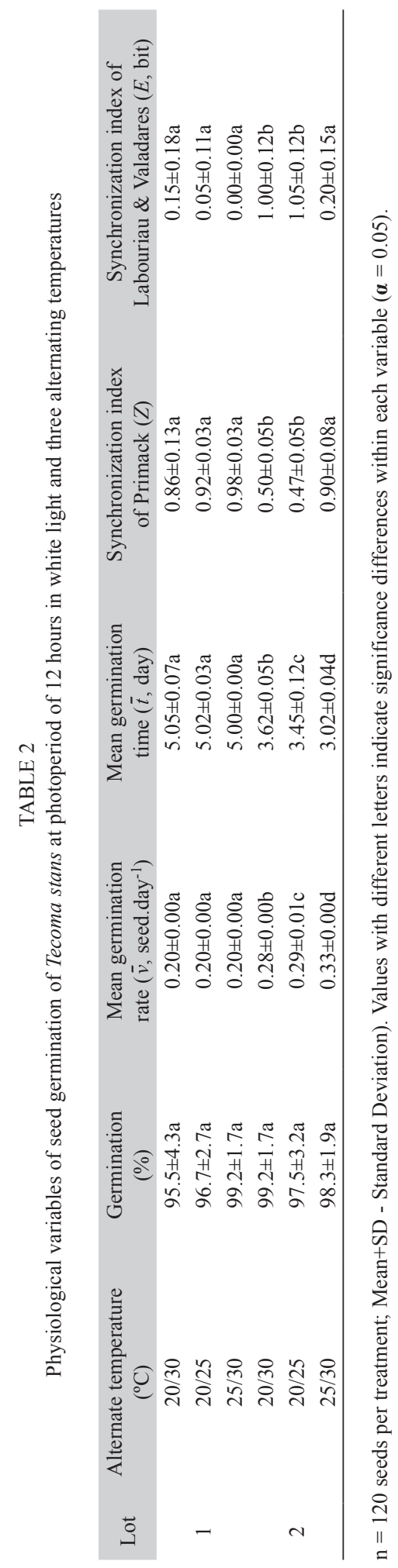

$0.000157 \leq \mathrm{P} \leq 0.000166 ; E: 0.000157 \leq \mathrm{P} \leq$ $0.000158)$, meaning that at these alternating temperature, the seeds of lot two germinated more asynchronously.

Effect of light and temperature on germination: Germination was high in all treatments, except for the temperature of $25 / 30$ ${ }^{\circ} \mathrm{C}$ in darkness, red light (R), and far-red light (FR) (Fig. 1). More than $90 \%$ of the seeds in both lots germinated whenever they were exposed to the alternating temperature $20 / 30$ ${ }^{\circ} \mathrm{C}$ or $20 / 25{ }^{\circ} \mathrm{C}$ (Tukey, $0.770 \leq \mathrm{P} \leq 1.000$ ), regardless of the quality of light to which the seeds were exposed. In contrast, at $25 / 30{ }^{\circ} \mathrm{C}$ with the absence of white light, approximately half of the seeds of each treatment failed to germinate ( $\mathrm{GP}=45-65 \%$, Tukey, $0.596 \leq \mathrm{P}$ $\leq 1.000$ ). The differences between these percentages were approximately $45 \%$ (the mean percentage of the high values was $\sim 98 \%$ and of the low values was $\sim 53 \%$ ), and the differences were statistically significant (Tukey, $0.00018 \leq \mathrm{P} \leq 0.00463)$. Thus, two patterns of germination were observed that depended on the interaction between light and temperature: a pattern in which seeds responded positively to all the alternating temperatures tested in the presence or absence of white light at mean temperatures between $21.7^{\circ} \mathrm{C}\left(20 / 25^{\circ} \mathrm{C}\right)$ and 23.3 ${ }^{\circ} \mathrm{C}\left(20 / 30^{\circ} \mathrm{C}\right)$, and regardless of any additional prior stimulus (i.e., R-enriched or FR-enriched light), and another pattern, where half of the seeds responded negatively to the absence of white light at a higher mean temperature of $26.7{ }^{\circ} \mathrm{C}\left(25 / 30^{\circ} \mathrm{C}\right)$, regardless of any prior light stimulus.

The seeds that had not germinated at 25/30 ${ }^{\circ} \mathrm{C}$ in the absence of white light responded positively when they were exposed to photoperiods of 12 hours of white light at this same temperature, reaching germination values higher than $90 \%$, thereby confirming that the group of seeds that had not germinated at the end of the experiment ( $\sim 53 \%)$ had not died.

Germination over time: Germination varied considerably in terms of the cumulative 

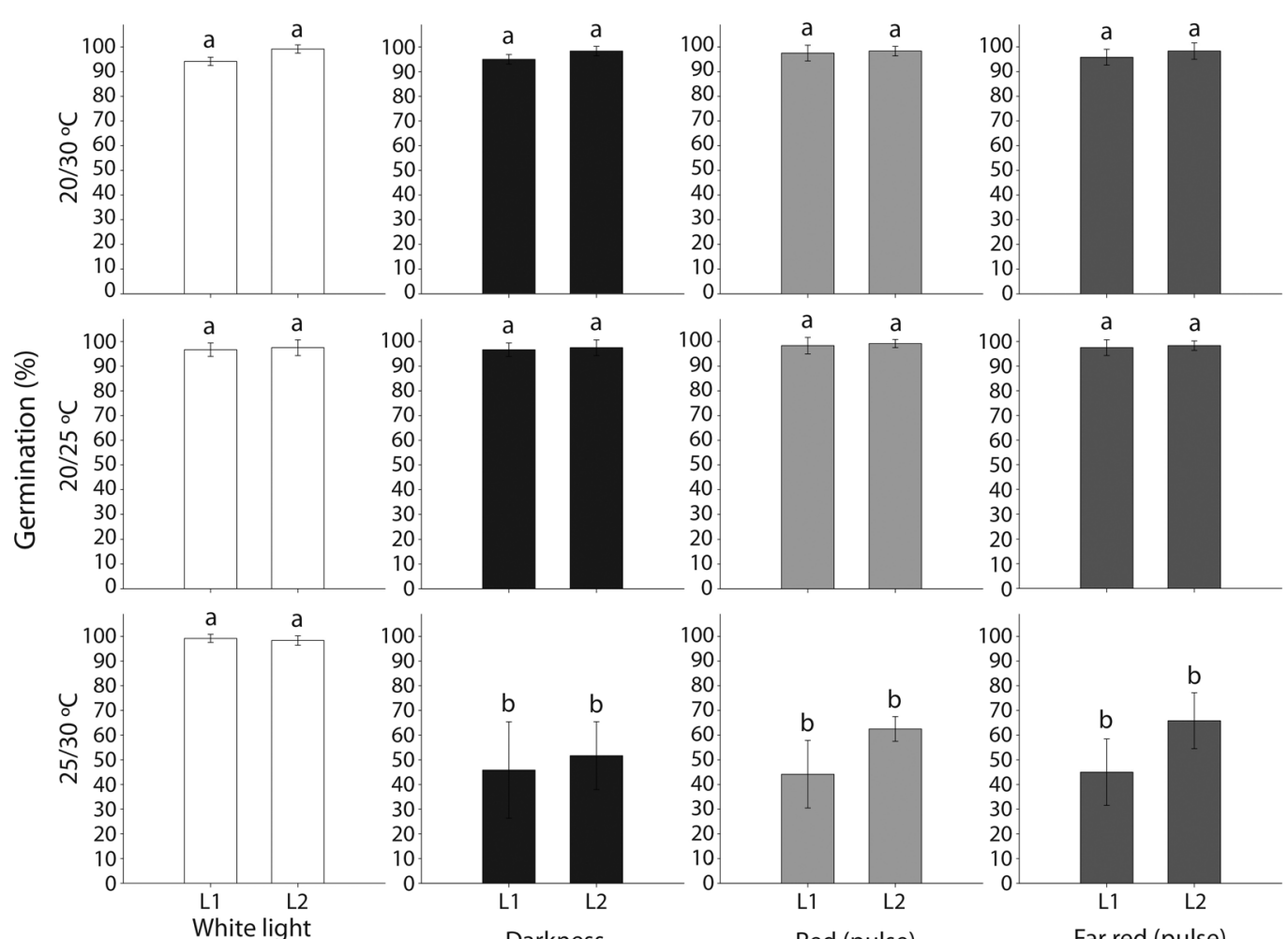

(12 hours photoperiod)
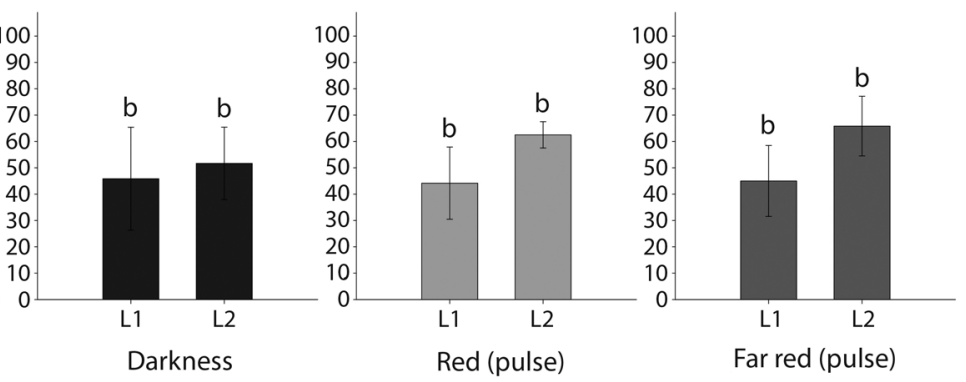

Seed lot / Light quality

Fig. 1. Seed germination of two seed lots (L1 and L2) of Tecoma stans at four light qualities and three alternating temperatures $(n=120$ seed per treatment). Vertical bars show the standard deviation. Bars with different letters indicate significance differences $(\boldsymbol{\alpha}=0.05)$.

number of seeds that germinated (GP) over time in each treatment with light quality and in the values of mean germination rates, mean germination time and the synchronization indexes. Three days after the germination experiment was initiated, seeds exposed to white light began to respond positively, reaching approximately $43 \%$ of germination, whereas the rest did not respond (0\%) (Fig. 2). On day four, seeds treated with the absence of white light responded positively. Of these, seeds exposed to a prior pulse of $\mathrm{R}$ light achieved a higher germination (5.8\% higher) than those exposed to a pulse of FR light and those exposed to total darkness; however, this difference was not significant (Tukey, $0.268 \leq \mathrm{P} \leq 1.000$ ). In the same amount of time, seeds exposed to white light achieved more than $90 \%$ of germination
(Tukey, $\mathrm{P}=0.000174$ ). On day five, seeds exposed to darkness and to $\mathrm{R}$ light displayed approximately $20 \%$ of germination, whereas those exposed to FR light displayed $\sim 9 \%$. Although these differences in percentage are not statistically significant (Tukey, $0.639 \leq \mathrm{P}$ $\leq 0.644$ ), they are considerable, given that an additional $11 \%$ of seeds germinated. In white light, seeds reached $98.3 \%$ of germination (Tukey, $\mathrm{P}=0.000174$ ). On the final day of the study (i.e. day six), seeds in FR light displayed an increase in germination, reaching up 55.8 $\%$, a value close statistically to that of the seeds in total darkness $(72.5 \%)$ (Tukey, $\mathrm{P}=0.515)$, whereas seeds in R light reached only $39.2 \%$ at the end of the test (Tukey, $\mathrm{P}=0.00767$ for the comparison against GP in darkness, $\mathrm{P}=$ 0.000174 in white light and $\mathrm{P}=0.601$ in $\mathrm{FR}$ 


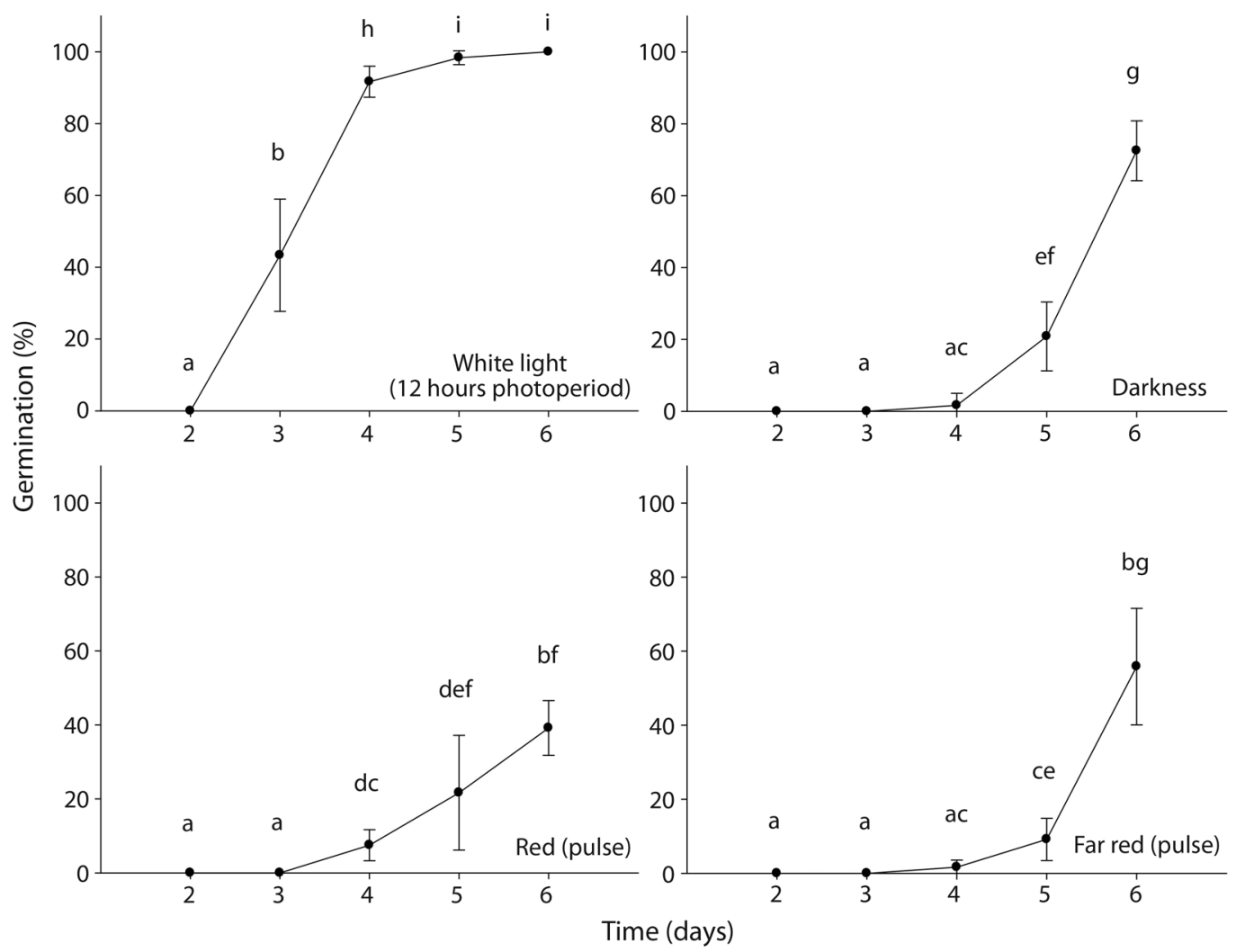

Fig. 2. Seed germination of Tecoma stans at four light qualities and an alternating temperature of $20 / 30^{\circ} \mathbf{C}-16 / 8 \mathrm{~h}(\mathrm{n}=$ 120 seeds per treatment). Vertical bars show the standard deviation. Germination percentages with different letters indicate significance differences $(\boldsymbol{\alpha}=0.05)$.

light). On this same day of the experiment, seeds in white light reached $100 \%$ of germination. The seeds that failed to germinate in these treatments responded positively when after that, were exposed to photoperiods of 12 hours of white light and achieved nearly 100 $\%$ germination within two days of experiment completion (i.e. day eight).

On the other hand, the germination of seeds exposed to white light during the six days of the experiment was significantly faster than in the other treatments in the absence of white light (Table 3) (Tukey, $0.00019 \leq \mathrm{P} \leq 0.00020$ ). In the absence of light, seeds took approximately five days to germinate, whereas seeds exposed to white light took approximately three days to reach a high value of GP (Tukey, 0.00019 $\leq \mathrm{P} \leq 0.00020$ ). Although, the differences in synchronization between the treatments were not statistically remarkable (Tukey, Z: 0.074 $\leq \mathrm{P} \leq 0.779$, with the exception of white light vs. $\mathrm{R}$ light $\mathrm{P}=0.0069$; Tukey, $E$ : $0.1615 \leq \mathrm{P}$ $\leq 0.999$ ), ecologically important differences were observed in the values obtained, in that germination in the presence of white light was explosive but more asynchronous than in the remaining treatments. Hence, although T. stans seeds germinated under different conditions of light quality when the alternating temperature of the environment is between 20 and $30{ }^{\circ} \mathrm{C}$, as noted above, the absence of white light at 12 hours of photoperiods affects the rate germination and synchronization of this process.

Storage behavior: The germination of seeds stored in different conditions of 
TABLE 3

Effect of light quality on seed germination of Tecoma stans at alternating temperature $20 / 30{ }^{\circ} \mathrm{C}-16 / 8$

\begin{tabular}{lcccc}
\multicolumn{1}{c}{ Light quality } & $\begin{array}{c}\text { Mean germination rate } \\
\left(\bar{v}, \text { seed.day }{ }^{-1}\right)\end{array}$ & $\begin{array}{c}\text { Mean germination } \\
\text { time }(\bar{t}, \text { day })\end{array}$ & $\begin{array}{c}\text { Synchronization index } \\
\text { of Primack }(Z)\end{array}$ & $\begin{array}{c}\text { Synchronization index } \\
\text { of Labouriau \& Valadares } \\
(E, \text { bit })\end{array}$ \\
$\begin{array}{l}\text { White Light } \\
\text { (12 hours of }\end{array}$ & $0.27 \pm 0.01 \mathrm{a}$ & $3.67 \pm 0.18 \mathrm{a}$ & $0.45 \pm 0.06 \mathrm{a}$ & $1.29 \pm 0.19 \mathrm{a}$ \\
photoperiod) & $0.18 \pm 0.01 \mathrm{bc}$ & $5.66 \pm 0.20 \mathrm{~b}$ & $0.33 \pm 0.18 \mathrm{ab}$ & $0.90 \pm 0.39 \mathrm{a}$ \\
Darkness & $0.19 \pm 0.01 \mathrm{~b}$ & $5.29 \pm 0.39 \mathrm{c}$ & $0.09 \pm 0.03 \mathrm{~b}$ & $0.93 \pm 0.50 \mathrm{a}$ \\
Red (pulse) & $0.17 \pm 0.00 \mathrm{c}$ & $5.79 \pm 0.11 \mathrm{~b}$ & $0.25 \pm 0.16 \mathrm{ab}$ & $0.71 \pm 0.29 \mathrm{a}$ \\
Far Red (pulse) & & & & \\
\hline
\end{tabular}

$\mathrm{h}(\mathrm{n}=120$ seeds per treatment) (Mean+SD - Standard Deviation). Values with different letters indicate significance differences within each variable $(\alpha=0.05)$.

temperature and moisture content was very high, obtaining GP values of more than $90 \%$ for all treatments (Fig. 3). A slight reduction in germination (i.e. reduction of $\sim 2.4 \%$ ) was observed in all treatments compared with the germination at time zero, except for $7.7 \%$

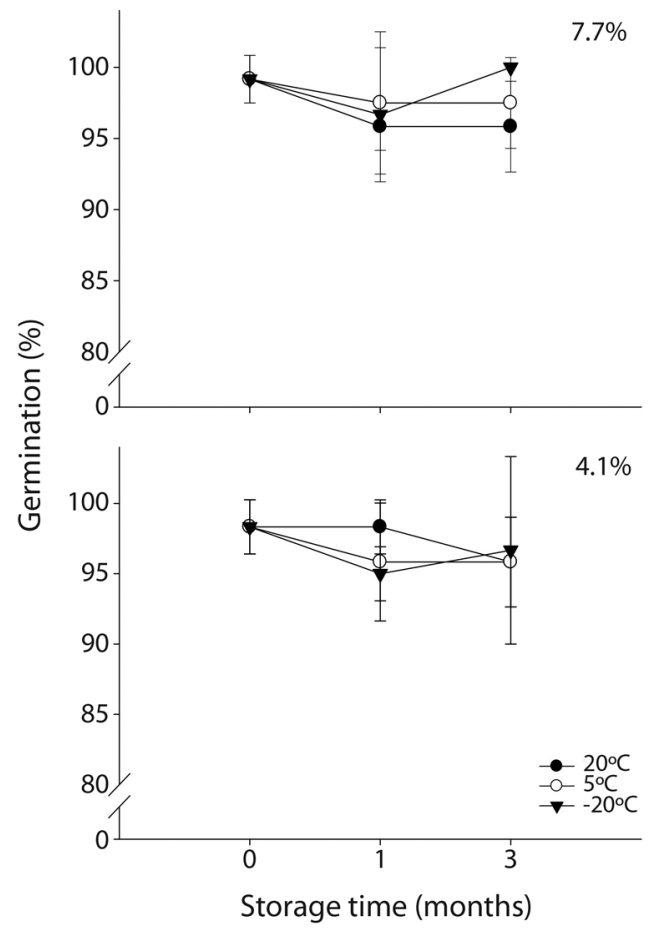

Fig. 3. Seed germination of Tecoma stans stored at two seed moisture contents (i.e. 7.7 and $4.1 \%$ ), three constant temperature and two storage times with a control a time cero. Seed germination test at alternating temperature $25 / 30{ }^{\circ} \mathrm{C}-16 / 8 \mathrm{~h}(\mathrm{n}=120$ seeds per treatment).
MC with $-20{ }^{\circ} \mathrm{C}$ for three months, where GP increased; however, this reduction was not statistically significant (Tukey, $0.387 \leq \mathrm{P} \leq 1.000$ ). Therefore, according to the protocol of Hong and Ellis (1996), this study confirmed that $T$. stans seeds display orthodox storage behavior.

\section{DISCUSSION}

The high germination ( $>90 \%$ ) obtained at three different alternating temperature (i.e. $20 / 25,25 / 30$ and $20 / 30{ }^{\circ} \mathrm{C}$ for $16 / 8 \mathrm{~h}$, with a 12 hour photoperiod of white light) shows that $T$. stans seeds display a high degree of flexibility to variations in the environmental temperature, a result also found in populations of T. stans introduced to Brazil (Socolowski et al., 2008). The seeds also exhibited a high degree of flexibility, in high mean germination rate and mean germination time at all three temperature ranges tested. The temperature variation studied reflects the temperature variation of the dry forest ecosystem in the Cauca River valley, where this species is located. Therefore, the germination response recorded in the laboratory simulates germination in the dry forest with these ranges of temperature variation and with similar conditions of photoperiodicity (i.e., direct white light for 12 hours). This result suggests that the wide geographical distribution of $T$. stans might be explained by the ability of its seeds to germinate at different temperatures when light is available, as it has 
been reported for other species of Bignoniaceae with broad distribution ranges, such as Tabebuia aurea (Silva Manso) S. Moore (Cabral, Barbosa, \& Simabukuro, 2003), Handroanthus serratifolius (Vahl) S.O. Grose (Santos, Sugahara, \& Takaki, 2005), T. rosea (Bertol.) DC (Socolowski \& Takaki, 2007; Vargas-Figueroa et al., 2015), and Jacaranda mimosifolia D. Don (Socolowski \& Takaki, 2004). However, this behavior is not common to all Bignoniaceae, as some species with relatively restricted distribution, such as Handroanthus chrysotrichus (A. DC.) Mattos and T. roseoalba (Ridl.) Sandwith (Santos et al., 2005; Stockman, Brancalion, Novembre, \& Chamma, 2007), have shown flexible responses to temperature variation, whereas the germination responses of some species with wide distribution, such as Handroanthus impetiginosus (DC.) Mattos (DC.) Standl (Oliveira, Carvalho, Silva, \& Borges, 2005), are not flexible. Therefore, the species of Bignoniaceae display a general tendency for flexibility in their germination responses to temperature variations, regardless of their geographical distribution in many cases, i.e. their wide germination responses appears to be not at least a direct causal of their wide geographical range. Nevertheless, species such as T. stans with flexible germination responses have an advantage in colonizing new sites for establishment. So, from an ecological perspective, species that have a flexible germination response but restricted geographic ranges might have additional requirements that prevent them from colonizing more locations. In this sense, the relatively wide temperature ranges at which germination of $T$. stans seeds occurs and their wide geographical distribution seem to show little environmental constrains for this species at the germination level, a typical trait of pioneer species. Besides, the greater synchronization of $T$. stans germination at alternating temperatures between 25 and $30{ }^{\circ} \mathrm{C}$ resembles the synchronization reported by Socolowski et al. (2008) at constant temperatures among populations introduced in Brazil. Thus, the optimal germination temperature of the local population of $T$. stans tested is $25 / 30{ }^{\circ} \mathrm{C}$.
Respecting the effect of light and temperature, the reduction of $c a .50 \%$ of $T$. stans germination in the absence of light and at a higher mean temperature $\left(=26.7^{\circ} \mathrm{C}\right.$ at $25 / 30$ ${ }^{\circ} \mathrm{C}$ ), that is, the secondary dormancy resulting from these conditions (Bewley \& Black, 1985), reflects the ability of these seeds to detect changes in light and temperature at a given site. This shows that external factors of light and temperature affect the colonization and establishment of $T$. stans at a site by triggering a sort of mechanism in seeds that prevents them from germinating at relatively high temperatures in the absence of light but causes them to germinate at high temperatures when light is available, such as in forest gaps. The decrease of germination at high temperature, even with a prior pulse of $\mathrm{R}$-enriched light (i.e. simulating the conditions of small forest gaps or sites with temporary incidence of sunlight rays) or with a pulse of FR-enriched light (i.e. simulating sites with dense understory canopy or beneath leaf litter), indicates that T. stans is apparently indifferent to variations in $\mathrm{R}$ and FR light applied in 15-min pulses. Nevertheless, these results highlight the importance of the interaction between these two factors (temperature and light) in the process of germination because, depending on the temperature, the seeds do or do not require direct light to germinate. Therefore, the bottlenecks faced by $T$. stans in the colonizing sites include 1) the degree of temperature fluctuation and 2) the availability of light at the site. The first factor could control the temporal variation in germination while the light could control the spatial one, as it has been proposed for others species of dry ecosystems (e.g. Escobar \& Cardoso, 2015).

T. stans seeds can germinate in the absence of light when the average temperature of the site is lower than $26.7^{\circ} \mathrm{C}\left(\right.$ e.g. $=21.7^{\circ} \mathrm{C}$, = $23.3{ }^{\circ} \mathrm{C}$ ). When seeds have physical dormancy, temperature plays a key role in breaking the barrier for germination (Baskin, 2003), but being that $T$. stans has not dormancy, the variation in the germination response in the absence of light raises the hypothesis that these seeds have some kind of physiological mechanism 
in their tissue that facilitates germination in darkness, such as a light-detection system mediated by phytochromes. The phytochromes can be generated in seeds in its active form $\left(\mathrm{P}_{\mathrm{fr}}\right)$ before it fully matures, and they remain stable in this form when the seed dries naturally in the fruit (Benvenuti et al., 2001; Pons, 2000). Thus, seeds of some species can germinate in the absence of light, as a prior stimulus is not required to transform the phytochrome into its active form. Perhaps the quality of light during fruit maturation generated phytochromes in the tissues of the T. stans seeds before they dried, and these phytochromes then promoted the germination in absence of light, as has been reported for Arabidopsis thaliana (L.) Heynh. (McCullough \& Shropshire, 1970), Portulaca oleracea L. (Gutterman, 1974), and Cucumis prophetarum L. (Gutterman, 1992; Gutterman $\&$ Porath, 1975). On the other hand, a metabolic-level explanation for why germination of $T$. stans seeds was halved in the absence of light at alternating temperature of $25 / 30{ }^{\circ} \mathrm{C}$ could be that the phytochrome changed from $\mathrm{P}_{\mathrm{fr}}$ to $\mathrm{P}_{\mathrm{r}}$, the inactive form. The transformation of this protein from the active to the inactive form can occur in the absence of light after a prolonged time in darkness at a high temperature, producing a group of inactive phytochromes throughout the seed tissues (Pons, 2000). In this sense, T. stans seeds might contain phytochrome A (PhyA) because this type of phytochrome has been associated with inhibiting germination in the dark at relatively high temperatures, such as when seeds are covered by a thick layer of leaf litter (Smith, 1995). Therefore, one of the next steps is to conduct studies to determine with certainty whether phytochromes are present in the tissues of $T$. stans by characterizing the multigenic family of these proteins for the species and producing varieties that carry mutations for each phytochrome (Shinomura, 1997), thereby identifying the types of phytochromes present and associating a physiological function to each one.

The mechanism of secondary dormancy in T. stans allows some of its seeds to prevent from germinating, which can be considered a bet-hedging strategy in which only a portion of the seeds dispersed at a given time germinate, while the rest enter to a dormancy state, awaiting a second opportunity to germinate in more favorable conditions (Donohue, Rubio, Burghardt, Kovach, \& Willis, 2010; Venable, 2007), such as when the temperature decreases. The secondary dormancy in T. stans seeds produced by the absence of light at high temperature demonstrates its ability to remain viable in unfavorable conditions, even when sufficient water and oxygen for germination are available. This ability seems to be of great importance for the formation of a soil bank of persistent seeds (Pons, 1991, 2000). In addition, this advantage gives the seed the potential to remain viable in the soil bank until a disturbance such as a tree falling or a landslide stimulates seeds by exposing to light or to a higher temperature at the site, causing them to germinate and colonize a newly formed forest gap. In this case, the next step might be to assess the effectiveness of secondary dormancy in T. stans seeds for the formation of these banks and measure their degree of persistence (Baskin \& Baskin, 2014).

The germination results of $T$. stans seeds make it possible to conclude that alternating temperature and light quality have no apparent effect on this process when average temperatures are below to $26.7^{\circ} \mathrm{C}\left(25 / 30{ }^{\circ} \mathrm{C}\right)$, in this case $23.3{ }^{\circ} \mathrm{C}\left(20 / 30{ }^{\circ} \mathrm{C}\right)$ and $21.7{ }^{\circ} \mathrm{C}(20 / 25$ $\left.{ }^{\circ} \mathrm{C}\right)$. However, the experiment of germination over time (i.e. the number of germinated seeds per day for each treatment of light quality) showed a delay in the germination response of seeds when exposed both to darkness and to prior pulses of $\mathrm{R}$ and FR light, although the same germination percentage was eventually achieved ( $\sim 100 \%$ on day eight), as in the treatments of light versus temperature. Therefore, at least at an alternating temperature of $20 / 30{ }^{\circ} \mathrm{C}$, variations in the quality of light also affect germination, as observed in the increase of the mean germination time and hence the reduction of the mean germination rate. This raises the possibility that $T$. stans also presents phytochrome B (PhyB), which has been associated with the detection of forest gaps through 
changes in the R:FR ratio (Smith, 1995). Shichijo, Katada, Tanaka, and Hashimoto (2001) believe that the time at which germination has been measured is crucial for detecting any effect in an experiment; otherwise, researchers would only record that germination occurred and conclude that the treatments tested has no effect on the process, as occurred with the treatments at alternating temperature of $20 / 25$ ${ }^{\circ} \mathrm{C}$ and $20 / 30{ }^{\circ} \mathrm{C}$. Hence, the importance of the time-destructive germination experiment given to simulate the effects of these factors in the colonization processes. The speed in which $T$. stans seedlings occupy a site with bright sunlight (Socolowski et al., 2008), and hence the effectiveness in which they use the resources in these places (i.e. the ecological niche hypothesis), confers advantages over individuals of other species. We would expect that in conditions of alternating temperature of $20 / 30{ }^{\circ} \mathrm{C}$, $T$. stans would germinate faster and therefore potentially colonize first sites with bright light (e.g. forest gaps and open areas), followed by areas with a high R/FR light ratio $660 \mathrm{~nm}$ (e.g. small forest gaps, understory sites with partially open canopy and forests edges), then sites with a low R/FR light ratio - $730 \mathrm{~nm}$ (e.g. understory sites with closed canopy and beneath the leaf litter) and, finally, completely dark places. That is why T. stans is named as a pioneer species of dry forests in its natural range of distribution. Seedlings and juveniles individuals of this species are expected to require bright light for optimal development. This pioneer plant behavior has been confirmed in exotic populations (Socolowski et al., 2008). In fact, individuals of $T$. stans are capable of colonizing more open areas, and eventually, they disappear from the site as the canopy coverage increases, that is, as the forest grow old (Grau, Arturi, Brown, \& Aceñolaza, 1997).

In the other hand, the assessment of storage behavior showed that the viability of $T$. stans seeds was not affected by short-term storage (i.e. one to three months). This fact confirms that these seeds display an orthodox storage behavior. This result is consistent with certain characteristics observed in T. stans seeds prior to the experiments. For example, seeds of this population have very low moisture content $(\sim 7 \%)$ when they are dispersed in the dry season, which implies a significant reduction in embryo metabolism. However, due to their orthodox behavior, it's expected from these seeds to be able to remain viable for a long time until a particular combination of environmental conditions activates the germination (Buitink \& Leprince, 2008). The orthodox trait is also consistent with Bignoniaceae family, where $97.5 \%$ of the species (i.e. 77 species) registered in Kew Seed Information Database (SID) with a storage behavior assignment based on experimental process or based on characteristics of the seed is classified as orthodox (RBG, 2017). Moreover, this family is quite absent in the literature about recalcitrant seeds (e.g. Farnsworth, 2000). Nevertheless, the probability of a seed population of being orthodox if there were a lack of dormancy is lower than the contrary, because most of the species with dormant seeds have an orthodox behavior ( $89.8 \%$ ), whereas $c a .65 \%$ of the species with non-dormant seeds have this behavior (Tweddle et al., 2003). In fact, some species of Handroanthus with non-dormant seeds have showed a decrease in their germination capability at low temperatures (Apóstolo, Larraburu, Gil, Zapater, \& Llorente, 2016), although these species have not yet a storage behavior classification. Thus, it's clear that not all non-dormant seeds are drying sensitive, because some species like many of Bignoniaceae family have the capacity of being viable when their lost moisture content.

The orthodox behavior of seeds may help the seed to find safe sites conducive to the successful establishment of the seedling (Harper, 1977). In the case of T. stans, this orthodox behavior contributes to the seeds' resistance to low-moisture environments, thus preserving their viability. These conditions can occur in degraded and disturbed areas and in large forest gaps, where light, temperature and moisture tend to fluctuate widely (Barton, Fetcher, \& Redhead, 1989; Bullock, 2000; Chazdon \& Fetcher, 1984; Denslow, 1980; Lawson, 
Armstrong-Mensah, \& Hall, 1970; Morgan, 1997). Consequently, these seeds can detect the optimal time and place to germinate and grow in the dry forests, where the periods of rainfall and drought are strong (Ewel, 1980; Mooney et al., 1995). The majority of species in areas of dry forest will display orthodox behavior (Hong \& Ellis, 1996; Tweddle et al., 2003; Vieira \& Scariot, 2006) because a direct association can be established between the site (i.e. ecosystem) where the species is most abundant and the storage behavior (Hong \& Ellis, 1996). Thus, the high tolerance to desiccation expected of $T$. stans seeds was supported by the results. However, some species of this ecosystems display recalcitrant or intermediate storage behavior (Carvalho, Arantes, \& Claudio, 2016; Daws, Garwood, \& Pritchard, 2005; Magistrali, José, Faria, \& Gasparin, 2013).

The orthodox storage behavior displayed by $T$. stans seeds makes them a good species candidates for its inclusion in ex situ conservation programs, as seeds with such behavior have greater long-term viability under controlled conditions (Hong \& Ellis, 1996). In addition, the orthodox behavior is important to ecological restoration plans, which seek to replant sites with native species and require a long-term storage of native species seeds. Therefore, an assessment of the long-term viability of T. stans seeds is necessary. This assessment requires the use of improved longevity equations derived from accelerated aging experiments to determine the maximum time the seeds might be stored (Ellis \& Roberts, 1980; Probert, Daws, \& Hay, 2009) in ex situ seed banks before their viability begins to decrease. In fact, at least one model that predicts the response of seeds to drying (Daws, Garwood, \& Pritchard, 2006) has been developed, thereby providing another way to estimate seeds behavior in storage conditions. Since desiccation tolerance can vary among individuals of the same species in dry forest ecosystems (Cervantes, Ceccon, \& Bonfil, 2014), an assessment is necessary of the consistency of the orthodox storage behavior of T. stans seeds throughout their geographical distribution to determine the degree of variation of this characteristic within the species population. For plans focused on restoring tropical dry forest ecosystems in Latin America, the ability to rely on orthodox seeds of a pioneer species such as $T$. stans is an important reason to conserve the germplasm of several populations over the long term. The develop of knowledge about the differences in the requirements of $T$. stans seeds for ex situ storage conditions versus the requirements in situ storage conditions is required to develop appropriate protocols for the management of plant material in seed banks focused on ecological conservation and restoration (Leon-Lobos et al., 2012).

It is concluded that seed germination of a population of $T$. stans in the tropical dry forest is flexible to the temperature fluctuation (i.e. $20 / 30,20 / 25$ and $25 / 30{ }^{\circ} \mathrm{C}$ ), reaching a high germination percentage $(>90 \%)$ in temperatures between 21.7 and $26.7{ }^{\circ} \mathrm{C}$, but with an incidence of white light. In the absence of light, the seeds of $T$. stans are able to germinate at lower temperature $\left(\leq 23.3^{\circ} \mathrm{C}\right)$, while at higher temperature $\left(26.7^{\circ} \mathrm{C}\right)$ half of the seed population enter to a secondary dormancy $(\mathrm{GP}=45-65$ $\%)$. This secondary dormancy gives a potential advantage to $T$. stans as the seeds which could be buried in a particular place after the dispersion, are able to remain viable until the light and temperature conditions turn into an optimum range to germinate. On the other hand, the final seed germination was high and similar in R and FR light treatments at low temperature. However, the mean germination rate and the synchronization decreased significantly in comparison to white light treatment, and consequently the mean germination time increased. So, the ability of $T$. stans seeds to respond to the interaction of light and temperature allow us to propose a physiologic mechanism on the seed tissues of this species that argues it likely for them to be able to detect variation in light quality; this mechanism is probably mediated by phytochromes. Therefore, T. stans has a germination stage potentially successful in several environments with a wide light and temperature variation. Finally, the orthodox seed storage behavior of $T$. stans opens the possibility to 
include this species in ex situ seed conservation programs for restoration and recuperation of the tropical dry forest.

\section{ACKNOWLEDGMENT}

We thank Seed Laboratory of Universidad del Valle for allowing us to use their facilities to develop all the germination tests. CIAT International Center of Tropical Agriculture for letting us to store the seeds in the cold rooms at the Genetic Resources Unit. Río Pance Departmental Ecopark and Corpocuencas for allowing us to collected seeds from several T. stans trees located in the park. The Head of Research Office of Universidad del Valle for the translation of the manuscript.

\section{RESUMEN}

Germinación y conservación de semillas de la especie pionera, Tecoma stans (Bignoniaceae), del bosque seco tropical de Colombia. La germinación y la longevidad de las semillas de una especie bajo diferentes condiciones ambientales son fundamentales para las dinámicas ecológicas de una especie, debido a que son decisivas en el éxito de la misma en un ecosistema. Teniendo en cuenta esto, se estudió la germinación y el comportamiento en el almacenamiento de las semillas de una especie pionera de bosque seco tropical (Tecoma stans) a nivel de laboratorio, para establecer el efecto de diferentes condiciones ambientales en una población local de árboles. Dos lotes de semillas recolectados en julio 2011, de Cali (Colombia), se evaluaron a tres temperaturas alternadas $(20 / 30,20 / 25$, $25 / 30^{\circ} \mathbf{C} ; 16 / 8 \mathrm{~h}$ ) y cuatro calidades de luz (fotoperiodo de 12 horas de luz blanca, oscuridad, y 15 minutos de luz roja -R y roja lejana -RL). Se registró la germinación final para todos los tratamientos; para el tratamiento de luz blanca se registró la germinación diaria para calcular la tasa media de germinación, el tiempo medio de germinación y dos índices de sincronización. Para evaluar el efecto de la calidad de luz sobre las variables fisiológicas, se realizó una prueba de germinación destructiva. Para esta prueba, otro lote de semillas fue puesto a las mismas condiciones de luz usando una temperatura alternada de $20 / 30^{\circ} \mathrm{C}-16$ / 8 h, registrando la germinación durante seis días para cada tratamiento. Además, se almacenaron semillas a dos contenidos de humedad $(7.7,4.1 \%)$ y a tres temperaturas de almacenamiento $\left(20,5,-20^{\circ} \mathrm{C}\right)$, durante dos periodos de tiempo (uno y tres meses); se realizó una prueba de germinación a cada tratamiento. Cuatro repeticiones de 35 semillas por cada tratamiento se usaron en cada experimento. La germinación fue alta $(\mathrm{PG}>90 \%)$ en todas las temperaturas alternadas con luz blanca, mientras que en los tratamientos de luz R, RL y en oscuridad, la germinación fue igualmente exitosa a bajas temperaturas, pero a temperaturas más altas la mitad de las semillas entraron en latencia secundaria $(\mathrm{PG}=45-65 \%)$. Sin embargo, la tasa media de germinación y la sincronización en R y RL disminuyeron significativamente en comparación con el tratamiento de luz blanca y consecuentemente el tiempo medio de germinación aumentó. El comportamiento de las semillas de T. stans en el almacenamiento es ortodoxo debido a la alta germinación obtenida ( $\mathrm{PG}>90 \%$ ) en todos los tratamientos. En conclusión, las semillas de $T$. stans tienen una respuesta germinativa negativa a temperaturas de incubación alta en ausencia de luz blanca, donde entran a latencia secundaria. En contraste, un ambiente con baja temperatura y sin luz blanca retrasa la germinación, pero al final las semillas son capaces de alcanzar los mismos valores de germinación. Esta dependencia de las semillas a la luz incidente en condiciones limitantes sugiere la presencia de un mecanismo fisiológico en los tejidos de esta especie, probablemente mediado por fitocromos. Finalmente, el comportamiento ortodoxo de las semillas de T. stans en el almacenamiento abre la posibilidad de incluirla en programas de conservación ex situ para la restauración y recuperación del bosque seco tropical; no obstante, se deben llevarse a cabo pruebas más largas para evaluar el mantenimiento de esta característica por periodos de tiempo más largos.

Palabras clave: latencia secundaria; fitocromo; banco de semillas del suelo; comportamiento de las semillas en el almacenamiento; conservación ex situ; cambio climático.

\section{REFERENCES}

Alvarado-López, S., Soriano, D., Velázquez, N., OrozcoSegovia, A., \& Gamboa-deBuen, A. (2014). Priming effects on seed germination in Tecoma stans (Bignoniaceae) and Cordia megalantha (Boraginaceae), two tropical deciduous tree species. Acta Oecologica, 61, 65-70. DOI: 10.1016/j.actao.2014.10.007

Apóstolo, N. M., Larraburu, E. E., Gil, M. N., Zapater, M. A., \& Llorente, B. E. (2016). In vitro and ex vitro germination of three Handroanthus species. Bonplandia, 25(1), 5-15. Retrieved from: https://doaj.org/article/ ead4f7be6a8b49c7a98f59f7de059285

Arcila, A. M., Valderrama, C., \& Chacón, P. (2012). Estado de fragmentación del bosque seco de la cuenca alta del río Cauca, Colombia. Biota Colombiana, 13(2), 86-101. Retrieved from: http://www.humboldt. org.co/images/Atlas de paramos/Biota13(2)-Bosque Seco.pdf

Barton, A. M., Fetcher, N., \& Redhead, S. (1989). The relationship between treefall gap size and light flux in a neotropical rain forest in Costa Rica. Journal of Tropical Ecology, 5(4), 437-439. DOI: 10.1017/ S0266467400003898 
Baskin, C. C. (2003). Breaking physical dormancy in seeds - focussing on the lens. New Phytologist, 158, 227238. DOI: $10.1046 / \mathrm{j} .1469-8137.2003 .00751 . x$

Baskin, C. C., \& Baskin, J. M. (2014). Seeds: Ecology, biogeography and evolution of dormancy and germination (2nd ed.). San Diego, California: Academy Press.

Benvenuti, S., Macchia, M., \& Miele, S. (2001). Light, temperature and burial depth effects on Rumex obtusifolus seed germination and emergence. Weed Research, 41, 177-186. DOI: 10.1046/j.1365-3180.2001.00230.x

Bewley, J. D. (1997). Seed Germination and dormancy. The Plant Cell, 9(7), 1055-1066. DOI: 10.1105/ tpc.9.7.1055

Bewley, J. D., \& Black, M. (1985). Seeds: phisiology of development and germination. New York: Plenum Press.

Bittencourt, N. S., \& Semir, J. (2005). Late acting selfincompatibility and other breeding systems in Tabebuia (Bignoniaceae). International Journal of Plant Sciences, 166(3), 493-506. DOI: 10.1086/428758

Buitink, J., \& Leprince, O. (2008). Intracellular glasses and seed survival in the dry state. Comptes Rendus - Biologies, 331(10), 788-795. DOI: 10.1016/j. crvi.2008.08.002

Bullock, J. M. (2000). Gaps and seedling colonization. In M. Fenner (Ed.), Seed: the ecology of regeneration in plant communities (pp. 375-395). New York: CABI Publishing.

Cabral, E. L., Barbosa, D. C. D. A., \& Simabukuro, E. A. (2003). Armazenamento e germinação de sementes de Tabebuia aurea (manso) Benth. \& Hook. f. ex. S. Moore. Acta Botanica Brasilica, 17(4), 609-617. DOI: $10.1590 / \mathrm{S} 0102-33062003000400013$

Cárdenas-Henao, M., Londoño-Lemos, V., Llano-Almario, M., González-Colorado, Á., Rivera-Hernández, K., Vargas-Figueroa, J. A., ... Moreno-Cavazos, M. P. (2015). Fenología de cuatro especies arbóreas de bosque seco tropical en el Jardín Botánico Universitario, Universidad del Valle (Cali), Colombia. Actualidades Biológicas, 37(103), 121-130. DOI: 10.17533/udea. acbi.v37n103a01

Carvalho, R., Arantes, T., \& Claudio, A. (2016). Physiological classification of forest seeds regarding the desiccation tolerance and storage behaviour. CERNE, 22(1), 85-92. DOI: 10.1590/01047760201622012064

Ceccon, E., \& Hernández, P. (2009). Seed rain dynamics following disturbance exclusion in a secondary tropical dry forest in Morelos, Mexico. Revista de Biologia Tropical, 57(1-2), 257-269. DOI: 10.15517/ rbt.v57i1-2.11319

Ceccon, E., Olmsted, I., Vázquez-Yanes, C., \& CampoAlves, J. (2002). Vegetación y propiedades del suelo en dos bosques tropicales secos de diferente estado regeneracional en Yucatán. Agrociencia, 36(1), 621631. DOI: 10.17129 /botsci.96

Cervantes, M., Ceccon, E., \& Bonfil, C. (2014). Germination of stored seeds of four tree species from the tropical dry forest of Morelos, Mexico. Botanical Sciences, 92(2), 281-287. DOI: 10.17129/botsci.96

Chazdon, R. L., \& Fetcher, N. (1984). Photosynthetic light environments in a lowland tropical rain forest in Costa Rica. Journal of Ecology, 72(2), 553-564. DOI: $10.2307 / 2260066$

Chízmar, C., De Gracia, J., \& Hoyos, M. (2015). Reforestation with native species in the dry lands of Panama. Conservation Leadership Programme: Final Report. Panama City, Panama: Conservation Leadership Programme. Retrieved from: http://www.conservationleadershipprogramme. org/media/2016/03/02141513 Panama_FinalReport_Reforestation-with-Native-Species-in-the-DryLands_29thSep15.pdf

Da Silva, J. A., Reis, T. E. D. S., \& Reis, L. C. (2008). Análise da infestação do amarelinho (Tecoma stans) na zona rural do município de Bandeirantes - Paraná, Brazil. Semina: Ciências Agrárias, 29(1), 83-92. DOI: $10.5433 / 1679-0359.2008 v 29 n 1 p 83$

Daws, M. I., Garwood, N. C., \& Pritchard, H. W. (2005). Traits of recalcitrant seeds in a semi-deciduous tropical forest in Panama: some ecological implications. Functional Ecology, 19(5), 874-885. DOI: 10.1111/j.1365-2435.2005.01034.x

Daws, M. I., Garwood, N. C., \& Pritchard, H. W. (2006). Prediction of desiccation sensitivity in seeds of woody species: a probabilistic model based on two seed traits and 104 species. Annals of Botany, 97(4), 667-674. DOI: 10.1093/aob/mcl022

Denslow, J. S. (1980). Gap patitioning among tropical rainforest trees. Biotropica, $12(2$ Supplement: Tropical Succession), 47-55. DOI: $10.2307 / 2388156$

Díaz, J. M. (2006). Bosque seco tropical Colombia. Cali, Colombia: Banco de Occidente, I/M Editores.

Dirzo, R., Young, H. S., Mooney, H. A., \& Ceballos, G. (2011). Introduction. In R. Dirzo, H. S. Young, H. A. Mooney, \& G. Ceballos (Eds.), Seasonally dry tropical forests: Ecology and conservation (pp. xi-xiii). Cambridge, Massachussetts: Cambridge University Press.

Donohue, K., Rubio, R., Burghardt, L., Kovach, K., \& Willis, C. G. (2010). Germination, postgermination adaptation, and species ecological ranges. Annual Review of Ecology, Evolution, and Systematics, 41(1), 293-319. DOI: 10.1146/annurev-ecolsys-102209-144715

Ellis, R. H., Hong, T. D., \& Roberts, E. H. (1990). An intermediate category of seed storage behaviour? I. 
Coffee. Journal of Experimental Botany, 41(230), 1167-1174. DOI: $10.1093 / \mathrm{jxb} / 41.9 .1167$

Ellis, R. H., \& Roberts, E. H. (1980). Improved equations for the prediction of seed longevity. Annals of Botany, 45(1), 13-30. Retrieved from: http://www.jstor.org/ stable/42756667

Escobar, D. F., \& Cardoso, V. J. M. (2015). Germinación y latencia de semillas de Miconia chartacea (Melastomataceae), en respuesta a luz, temperatura y hormonas vegetales. Revista de Biologia Tropical, 63(4), 1169-1184. DOI: $10.15517 /$ rbt.v63i4.17955

Escobar, D. F., \& Torres, A. M. (2013). Morphology, ecophysiology and germination of seeds of the neotropical tree Alibertia patinoi (Rubiaceae). Revista de Biología Tropical, 61(2), 547-556. DOI: 10.15517/ rbt.v61i2.11147

Espinal, L. S., \& Montenegro, E. (1977). Zonas de vida o formaciones vegetales de Colombia. Memoria explicativa sobre el mapa ecológico (Vol. XIII). Bogotá, D.C., Colombia: Ministerio de Hacienda y Crédito Público e Instituto Geográfico Agustín Codazzi.

Ewel, J. (1980). Tropical succession : mainfold routes to maturity. Biotropica, 12(2, Supplement: Tropical Succession), 2-7. DOI: 10.2307/2388149

Farnsworth, E. (2000). The ecology and physiology of viviparous and recalcitrant seeds. Annual Review of Ecology and Systematics, 31, 107-138. DOI: 10.1146/ annurev.ecolsys.31.1.107

Gentry, A. (2009). Flora de Colombia. Bignoniaceae. Bogotá, D.C., Colombia: Missouri Botanical Garden. Instituto de Ciencias Naturales, Facultad de Ciencias, Universidad Nacional de Colombia.

Grau, H. R., Arturi, M. F., Brown, A. D., \& Aceñolaza, P. G. (1997). Floristic and structural patterns along a chronosequence of secondary forest succession in Argentinean subtropical montane forests. Forest Ecology and Management, 95(2), 161-171. DOI: 10.1016/S0378-1127(97)00010-8

Gutterman, Y. (1974). The influence of the photoperiodic regime and red-far red light treatments of Portulaca oleracea L. plants on the germinability of their seeds. Oecologia, 17(1), 27-38. DOI: 10.1007/BF00345093

Gutterman, Y. (1992). Influence of daylength and red or far red light on the storage of ripe Cucumis prophetarum fruits, on seed germination in light. Journal of Arid Environment, 23, 443-449.

Gutterman, Y., \& Porath, D. (1975). Influences of photoperiodism and light treatments during fruits storage on the phytochrome and on the germination of Cucumis prophetarum L. and Cucumis sativus L. seeds. Oecologia, 18(1), 37-43. DOI: 10.1007/BF00350633
Harper, J. L. (1977). Population biology of plants. New York: Academic Press.

Hong, T. D., \& Ellis, R. H. (1996). A protocol to determine seed storage behaviour. Rome, Italy: International Plant Genetic Resource Institute. Retrieved from: http://cropgenebank.sgrp.cgiar.org/images/file/learning space/technicalbulletin1.pdf

IDEAM. (2005). Atlas climatológico de Colombia. Bogotá, D.C., Colombia: Instituto de Hidrología, Meteorología y Estudios Ambientales.

ISTA. (2017). International Rules for Seed Testing. Bassersdorf, Switzerland: International Seed Testing Association. DOI: 10.15258/istarules.2017.F

Kendrick, R. E., \& Spruit, J. P. (1977). Phototransformation of phytochrome. Photochemistry and Photobiology, 26, 201-214. DOI: 10.1111/j.1751-1097.1977. tb07473.x

Khurana, E., \& Singh, J. S. (2000). Influence of seed size on seedling growth of Albizia procera under different soil water levels. Annals of Botany, 86(6), 1185-1192. DOI: $10.1006 /$ anbo.2000.1288

Labouriaou, L. G., \& Valadares, M. E. B. (1976). On the germination of seeds of Calotropis procera (Ait.) Ait.f. Anais Da Academia Brasileira de Ciências, 48(2), 263-284.

Lawson, G. W., Armstrong-Mensah, K. O., \& Hall, J. B. (1970). A catena in tropical moist semi-deciduous forest near Kade, Ghana. Journal of Ecology, 58(2), 371-398. DOI: $10.2307 / 2258277$

Leon-Lobos, P., Way, M., Aranda, P. D., \& Lima, M. (2012). The role of ex situ seed banks in the conservation of plant diversity and in ecological restoration in Latin America. Plant Ecology \& Diversity, 5(2), 245-258. DOI: 10.1080/17550874.2012.713402

Lorenzi, H. (2000). Plantas daninhas do Brasil: terrestres, aquáticas, parasitas, tóxicas e medicinais (3rd ed.). São Paulo, Brazil: Nova Odessa- Instituto plantarum.

Madire, L. G., Wood, A., Williams, H. E., \& Neser, S. (2011). Potential agents for the biological control of Tecoma stans (L.) Juss. ex Kunth var. stans (Bignoniaceae) in South Africa. African Entomology, 19(2), 434-442. DOI: 10.4001/003.019.0216

Magistrali, P. R., José, A. C., Faria, J. M. R., \& Gasparin, E. (2013). Physiological behavior of Genipa americana L. seeds regarding the capacity for desiccation and storage tolerance. Journal of Seed Science, 35(4), 495-500. DOI: 10.1590/S2317-15372013000400011

McCullough, M., \& Shropshire, W. J. (1970). Physiological predetermination of germination responses in Arabidopsis thaliana (L.) Heynh. Plant \& Cell Physiology, 11, 139-148. DOI: 10.1093/oxfordjournals. pcp.a074485 
McLaren, K. P., \& McDonald, M. A. (2003). The effects of moisture and shade on seed germination and seedling survival in a tropical dry forest in Jamaica. Forest Ecology and Management, 183(1-3), 61-75. DOI: 10.1016/S0378-1127(03)00100-2

Mooney, H. A., Bullock, S. H., \& Medina, E. (1995). Introduction. In S. H. Bullock, H. A. Mooney, \& E. Medina (Eds.), Seasonally dry tropical forests (pp. 1-8). Cambridge, United Kingdom: Cambridge University Press.

Morgan, J. W. (1997). The effect of grassland gap size on establishment, growth and flowering of the endangered Rutidosis leptorrhynchoides (Asteraceae). Journal of Applied Ecology, 34(3), 566-576. DOI: $10.2307 / 2404907$

Nichols, M. A., \& Heydecker, W. (1968). Two approach to the study of germination data. Proceedings of International Seed Testing Association, 33(3), 531-540.

Oliveira, L. D., Carvalho, M. D., Silva, A. T. D., \& Borges, D. I. (2005). Temperatura e regime de luz na germinação de sementes de Tabebuia impetiginosa (Martius ex AP de Candolle) Standley e T. serratifolia Vahl Nich. Ciência E Agrotecnologia, 29(3), 642-648. DOI: 10.1590/S1413-70542005000300020

Otsamo, A., Adjers, G., Hadi, T. S., Kuusipalo, J., \& Vuokko, R. (1997). Evaluation of reforestation potential of 83 tree species planted on Imperata cylindrica dominated grassland. New Forests, 14(2), 127-143. DOI: 10.1023/A:1006566321033

Pelton, J. (1964). A survey of the ecology of Tecoma stans. Butler University Botanical Studies, 14(11), 53-88. Retrieved from: http://digitalcommons.butler.edu/ botanical/vol14/iss1/11/

Perera, G. A. D. (2007). Fate of seeds of Sri Lankan tropical dry forest species and their role in forest regeneration. In S. Turner, D. Merrittt, S. Clarke, L. Commander, \& K. Dixon (Eds.), Conference Proceedings. The Second International Society for Seed Science Meeting on Seeds and the Environment, Perth, Western Australia (p. 72). England, United Kingdom: International Society for Seed Science.

Pons, T. L. (1991). Induction of dark dormancy in seeds: Its importance for the seed bank in the soil. Functional Ecology, 5(5), 669-675. DOI: 10.2307/2389487

Pons, T. L. (2000). Seed responses to light. In M. Fenner (Ed.), Seed: the ecology of regeneration in plant communities (pp. 237-260). New York: CABI Publishing.

Primack, R. B. (1980). Variation in the phenology of natural populations of montane shrubs in New Zealand. Journal of Ecology, 68(3), 849-862. DOI: $10.2307 / 2259460$

Probert, R. J., Daws, M. I., \& Hay, F. R. (2009). Ecological correlates of ex situ seed longevity: a comparative study on 195 species. Annals of Botany, 104(1), 57-69. DOI: $10.1093 / \mathrm{aob} / \mathrm{mcp} 082$

Quesada, M., Sanchez-Azofeifa, G. A., Alvarez-Añorve, M., Stoner, K. E., Avila-Cabadilla, L., Calvo-Alvarado, J., ... Sanchez-Montoya, G. (2009). Succession and management of tropical dry forests in the Americas: Review and new perspectives. Forest Ecology and Management, 258(6), 1014-1024. DOI: $10.1016 /$ j.foreco.2009.06.023

Ranal, M. A., \& Santana, D. G. De. (2006). How and why to measure the germination process? Revista Brasileira de Botânica, 29(1), 1-11. DOI: 10.1590/ S0100-84042006000100002

RBG. (2017). Seed Information Database (SID). Version 7.1. Retrieved from: http://data.kew.org/sid/

Reis, F. C., Medina-Sotomayor, J. F., Garcia, D. B., Barroso, A. A. M., Albrecht, A. J. P., \& Filho, R. V. (2014). Germination and emergence of trumpet flower (Tecoma stans) under different environmental conditions. Planta Daninha, 32(2), 283-290. DOI: 10.1590/ S0100-83582014000200005

Roberts, E. H. (1973). Predicting the storage life od seeds. Seed Science \& Technology, 1, 499-514.

Rojas-Rodríguez, F., \& Torres-Córdoba, G. (2012). Árboles del Valle Central de Costa Rica: Reproducción Candelillo (Tecoma stans (L.) Kunth). Revista Forestal Mesoamericana Kurú (Costa Rica), 9(23), 47-48. DOI: $10.18845 / \mathrm{rfmk} . v 9 \mathrm{i} 23.492$

Santos, D. L., Sugahara, V. Y., \& Takaki, M. (2005). Efeitos da luz e da temperatura na germinacao de sementes de Tabebuia serratifolia (Vahl) Nich, Tabebuia chrysotricha (Mart. ex DC.) Standl. e Tabebuia roseo-alba (Ridl) Sand - Bignoniaceae. Ciência Florestal, 15(1), 87-92. DOI: 10.1590/S0100-84042003000200013

Shichijo, C., Katada, K., Tanaka, O., \& Hashimoto, T. (2001). Phytochrome A-mediated inhibition of seed germination in tomato. Planta, 213(5), 764-769. DOI: $10.1007 / \mathrm{s} 004250100545$

Shinomura, T. (1997). Phytochrome regulation of seed germination. Journal of Plant Research, 110(1), 151161. DOI: $10.1007 / \mathrm{BF} 02506854$

Smith, H. (1995). Physiological and ecological function within the phytochrome family. Annual Review of Plant Physiology, 46, 289-315. DOI: 10.1146/annurev.pp.46.060195.001445

Socolowski, F., \& Takaki, M. (2004). Germination of Jacaranda mimosifolia (D. Don - Bignoniaceae) seeds: Effects of light, temperature and water stress. Brazilian Archives of Biology and Technology, 47(5), 785-792. DOI: 10.1590/S1516-89132004000500014

Socolowski, F., \& Takaki, M. (2007). Seed germination and seedling emergence of Tabebuia rosea (Bertoloni) 
A.P. de Candolle (Bingoniaceae), an exotic species with invasive potential. Revista Árvore, 31(2), 229238. DOI: $10.1590 / \mathrm{S} 0100-67622007000200005$

Socolowski, F., Vieira, D. C. M., \& Takaki, M. (2008). Interaction of temperature and light on seed germination in Tecoma stans L. Juss. ex Kunth (Bignoniaceae). Brazilian Archives of Biology and Technology, 51(4), 723-730. DOI: 10.1590/S1516-89132008000400010

Stockman, A. L., Brancalion, P. H. S., Novembre, A. D. D. L. C., \& Chamma, H. M. C. P. (2007). Sementes de ipê-branco (Tabebuia roseo-alba (Ridl.) Sand. - Bignoniaceae): temperatura e substrato para o teste de germinação. Revista Brasileira de Sementes, 29(3), 139-143. DOI: 10.1590/S0101-31222007000300016

Tweddle, J. C., Dickie, J. B., Baskin, C. C., \& Baskin, J. M. (2003). Ecological aspects of seed desiccation sensitivity. Journal of Ecology, 91, 294-304. DOI: 10.1046/j.1365-2745.2003.00760.x

Vargas-Figueroa, J. A. (2012). Fisiología de semillas de Tecoma stans (Bignoniaceae), una especie del bosque seco tropical. Tesis de pregrado, Departamento de Biología, Facultad de Ciencias Naturales y Exactas, Universidad del Valle, Cali, Colombia.

Vargas-Figueroa, J. A., Duque-Palacio, O. L., \& TorresGonzález, A. M. (2015). Germinación de semillas de cuatro especies arbóreas del bosque seco tropical del Valle del Cauca, Colombia. Revista de Biología Tropical, 63(1), 249-261. DOI: 10.15517/rbt. v63i1.14123

Vargas, G. G., Werden, L. K., \& Powers, J. S. (2015). Explaining legume success in tropical dry forests based on seed germination niches: A new hypothesis. Biotropica, 47(3), 277-280. DOI: 10.1111/btp.12210

Venable, D. L. (2007). Bet hedging in a guild of desert annuals. Ecology, 88(5), 1086-1090. DOI: $10.1890 / 06-1495$

Vieira, D. L. M., \& Scariot, A. (2006). Principles of natural regeneration of tropical dry forests for restoration. Restoration Ecology, 14(1), 11-20. DOI: 10.1111/j.1526-100X.2006.00100.x

Walck, J. L., Hidayati, S. N., Dixon, K. W., Thompson, K., \& Poschlod, P. (2011). Climate change and plant regeneration from seed. Global Change Biology, 17(6), 2145-2161. DOI: 10.1111/j.1365-2486.2010.02368.x

Zar, J. H. (2010). Biostatistical analysis (5th ed.). Upper Saddle River, New Jersey: Prentice Hall.

Ziller, S. R. (2001). Plantas exóticas invasoras: a ameaçao da contaminação biológica. Ciência Hoje, 30(178), 77-79. 